\title{
Effects of Age, Postmortem Delay and Storage Time on Receptor-mediated Activation of G-proteins in Human Brain
}

\author{
Javier González-Maeso, Ph.D., Iratxe Torre, B.S., Rafael Rodríguez-Puertas, Ph.D.,
} Jesús A. García-Sevilla, M.D., Ph.D., José Guimón, M.D., Ph.D., and J. Javier Meana, M.D., Ph.D.

The influence of age, postmortem delay and freezing storage period on receptor-mediated G-protein activity was quantified in cortical membranes from 34 healthy subjects.

Concentration-response curves of the $\left[{ }^{35} S\right] G T P \gamma S$ binding stimulation by agonists for $\alpha_{2}$-adrenoceptors (UK14304),

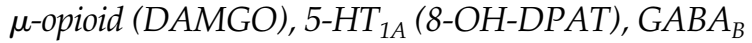
(baclofen) and muscarinic (carbachol) receptors were analyzed. Immunoreactivities of $G_{\alpha}$-protein subunits were also determined. Basal binding and UK14304, 8-OH-DPAT, and baclofen potency to stimulate $\left[{ }^{35}\right.$ S]GTP $\gamma S$ binding decreased with aging (1-88 years) without changes of efficacy. DAMGO-mediated stimulation increased both in potency and efficacy with aging. A negative correlation between age and immunoreactivity was observed for $G_{\text {air/2 }}$, but not for $G_{\alpha i 3^{-}}, G_{\alpha 0^{-}}$, and $G_{\alpha s}$-proteins. Neither [ $\left.{ }^{35} S\right] G T P \gamma S$ binding nor $G_{\alpha}$-proteins changed with the postmortem delay (8-92 h).

Basal $\left.{ }^{35} S\right] G T P \gamma S$ binding decreased with the sample storage period (1-85 months). A careful match between cases and controls should be taken into account when designing signal transduction studies in human disorders, specially for variables such as age and storage period.

[Neuropsychopharmacology 26:468-478, 2002]

(C) 2002 American College of Neuropsychopharmacology. Published by Elsevier Science Inc.
KEY WORDS: G-protein; Aging; Human brain; $\alpha_{2}$-adrenoceptor; 5-HT $\mathrm{T}_{1 \mathrm{~A}}$-serotonin receptor; $\mu$-opioid receptor

Heterotrimeric guanine nucleotide binding proteins (G-proteins) represent a widely used mechanism for signal transduction from membrane receptors to intracellular effectors. Activation of the receptors by their agonists promotes the exchange of GDP by GTP on heterotrimeric G-proteins, and this results in the dissociation of the $\alpha$

From the Department of Pharmacology, University of the Basque Country, E-48940 Leioa, Bizkaia, Spain (JG-M, IT, RR-P, JJM); and Clinical Research Unit, Department of Psychiatry, University of Geneva, HUG, Belle-Idée, CH-1225 Chêne-Bourg, Switzerland (JAG-S, JG, JJM).

Address correspondence to: Dr. J. Javier Meana, Department of Pharmacology, University of the Basque Country, E-48940 Leioa, Bizkaia, Spain. Fax: +34 944800 128; E-mail: kfpmemaj@lg.ehu.es

Received February 19, 2001; revised May 25, 2001; accepted July 16, 2001.

Online publication: 7/24/01 at www.acnp.org/citations/Npp 072401154. from $\beta \gamma$ subunits (Gilman 1987; Birnbaumer et al. 1990; Gudermann et al. 1997). The G-protein $\alpha$ subunit possesses the ability to initiate a variety of effector pathways that involves, among others, cAMP production, phospholipids hydrolysis and changes of ion channel permeability. The subsequent GTP hydrolysis by the $\mathrm{G}_{\alpha}$-protein subunit facilitates the reassociation of the heterotrimeric protein ( $\alpha$ and $\beta \gamma$ subunits) which leads G-protein to the inactive GDP-bound state. The heterogeneity of $\alpha$ subunits serves to divide G-proteins into the major classes $\left(G_{i}, G_{o}, G_{s}, G_{q}\right.$, etc.) (Gilman 1987; Simon et al. 1991).

The $\left[{ }^{35} \mathrm{~S}\right] \mathrm{GTP} \gamma \mathrm{S}$ binding assay has been developed as a functional method to assess the receptor-mediated activation of G-proteins. The binding of the radiolabeled poorly-hydrolyzable GTP analog [ $\left.{ }^{35} \mathrm{~S}\right] \mathrm{GTP} \gamma \mathrm{S}$ measures the exchange of GDP by GTP (or [ $\left.{ }^{35} \mathrm{~S}\right] \mathrm{GTP} \gamma \mathrm{S}$ ) on the $\mathrm{G}_{\alpha}$ protein subunit and in this way it reflects directly the 
receptor-activation induced by the different agonists. The approach has been used in reconstituted systems of purified proteins (Cerione et al. 1986; Florio and Sternweis 1989), tissue membrane homogenates (Hilf et al. 1989; Olianas and Onali 1996; Elliot and Reynolds 1999; Gessi et al. 1999), lysate of cells transfected with cloned receptors (Lazareno and Birdsall 1993; Newman-Tancredi et al. 1997; Peltonen et al. 1998), tissue autoradiography (Sim et al. 1995; Dupuis et al. 1999) and immunoprecipitation assays (Wang and Friedman 1994). Recently, we have demonstrated the applicability of the $\left[{ }^{35} \mathrm{~S}\right] \mathrm{GTP} \gamma \mathrm{S}$ binding assay to postmortem human brain membrane homogenates and sections (González-Maeso et al. 2000; Meana et al. 2000; Rodríguez-Puertas et al. 2000).

Biochemical and functional alterations of G-protein coupled receptors (GPCRs) have been repeatedly postulated in the pathophysiology of several neurological and psychiatric disorders. Contributions have usually come from in vitro or in vivo receptor radioligand binding studies. Additional contributions suggest that modifications of G-protein expression and/or function could also be implicated in some of these brain disorders (Manji 1992; Young et al. 1993; Escribá et al. 1994; Wang and Friedman 1994; Cowburn et al. 1996; Friedman and Wang 1996; Pacheco et al. 1996; Spiegel 1996; Jope et al. 1998). The responsiveness to many hormones and neurotransmitters is altered during senescence. Some of these alterations are associated with reduced receptor densities (Dewey et al. 1990; Dillon et al. 1991; Pascual et al. 1991; Nordberg et al. 1992; Arranz et al. 1993; Sastre and García-Sevilla 1994) while others involve age-related alterations in signal transduction elements beyond receptors (Young et al. 1991; Cowburn et al. 1992, 1994; Sastre and García-Sevilla 1994; Greenwood et al. 1995; Busquets et al. 1996; Li et al. 1996).

The use of autopsy tissue represents the only approach that permits an analysis of the pathophysiological conditions of human brain at receptor/G-protein coupling level. However, postmortem studies present several methodological problems including the unavoidable delays between death and tissue dissection (postmortem delay) and the length and temperature of sample storage prior to assay (Perry and Perry 1983). For the most part, postmortem human brain studies have examined receptor agonist/antagonist radioligand binding and immunoreactive levels of the different G-proteins. In contrast, restricted data are available on the functional responses of signal transduction pathways to receptor activation in postmortem human brain, probably due to a substantial loss of receptors and/or G-proteins during postmortem delays and freezing storage periods (Odagaki et al. 1998; Happe et al. 1999).

The aim of the present study was to quantify accurately both receptor-mediated activation of G-proteins and G-proteins themselves in a large number of post- mortem human brain samples and to investigate their relationship with aging and with limiting parameters such as the postmortem delay and the freezing storage period.

\section{SUBJECTS AND METHODS}

\section{Subject Selection and Brain Samples}

Human brains were obtained at autopsy in the Basque Institute of Legal Medicine (Bilbao, Spain) and in the Institute of Forensic Medicine (Geneva, Switzerland). In typical conditions, the corpse is usually refrigerated within $3-5 \mathrm{~h}$ after death and stored at refrigeration temperature $\left(4^{\circ} \mathrm{C}\right)$ until autopsy. Samples from prefrontal cortex (Brodmann's area 9) were dissected at the time of autopsy and immediately stored at $-70^{\circ} \mathrm{C}$ until assay. Collection procedures were performed in accordance with the protocol for postmortem human brain research of the Basque Institute of Legal Medicine. The study was approved by the Research and Ethics Boards of both the Medical School of the Basque Country, Spain and the Department of Psychiatry, University of Geneva, Switzerland.

Samples were obtained (collecting period 1991-1999) from subjects without a known history of neurological or psychiatric disorders and who had mainly died by sudden accidents; other causes of death were myocardial infarction $(n=2)$ and asphyxia $(n=1)$. The samples of subjects with a positive result in the screening for psychotropic drugs were excluded from assays. Ethanol was detected in four subjects (blood concentration, $1.21 \pm 0.5 \mathrm{mg} / \mathrm{ml}$ ). A total number of 34 subjects ( $20 \mathrm{fe}-$ male, 14 male) that provided a wide range for the variables to be evaluated in the study were used.

\section{Membrane Preparations}

Membrane preparations were performed as reported in detail previously (González-Maeso et al. 2000). Briefly, cortical tissues were homogenized in ice-cold Trisbuffer (50 mM Tris- $\mathrm{HCl}, 3 \mathrm{mM} \mathrm{MgCl} 2,1 \mathrm{mM}$ EGTA, $\mathrm{pH}$ 7.4) supplemented with $1 \mathrm{mM}$ dithiothreitol (DTT) and $0.25 \mathrm{M}$ sucrose. Cellular $\mathrm{P}_{2}$ fractions were prepared by sequential centrifugations and resuspensions in Trisbuffer. Final aliquots were stored at $-70^{\circ} \mathrm{C}$ for binding and Western blot assays.

\section{$\left[{ }^{35}\right.$ S]GTP $\gamma$ S Binding Assays}

$\left.{ }^{35} \mathrm{~S}\right] \mathrm{GTP} \gamma \mathrm{S}$ binding assays were performed as already described (González-Maeso et al. 2000). Briefly, after thawing, $80 \mu \mathrm{g} / \mathrm{ml}$ of membrane proteins were incubated at $30^{\circ} \mathrm{C}$ for $120 \mathrm{~min}$ in incubation buffer $(50 \mathrm{mM}$ Tris- $\mathrm{HCl}, 3 \mathrm{mM} \mathrm{MgCl} 2,0.2 \mathrm{mM}$ DTT, 1 mM EGTA, 100 $\mathrm{mM} \mathrm{NaCl}$ and $50 \mu \mathrm{M}$ GDP, $\mathrm{pH} 7.4$ ) containing $0.5 \mathrm{nM}$ $\left[{ }^{35} \mathrm{~S}\right] \mathrm{GTP} \gamma \mathrm{S}$. Selective agonist drugs for several GPCRs 
were included in the assay to evaluate in a concentration-dependent manner $\left(10^{-10}-10^{-3} \mathrm{M}\right.$; eight concentrations) the receptor-mediated activation of $\left[{ }^{35} \mathrm{~S}\right] \mathrm{GTP} \gamma \mathrm{S}$ binding to G-proteins. All experiments were performed in triplicate. Nonspecific binding was determined in the presence of $10 \mu \mathrm{M}$ unlabeled GTP $\gamma \mathrm{S}$. The specific $\left.{ }^{35} \mathrm{~S}\right] \mathrm{GTP} \gamma \mathrm{S}$ binding in the absence of any agonist drug was assumed as the basal binding. The reaction was terminated by rapid vacuum filtration through Whatman GF/C glass fiber filters and the remaining bound radioactivity was quantified by liquid scintillation spectrophotometry.

\section{Immunoblot Analysis of G-protein $\alpha$-Subunits and Quantitation of the Specific Immunoreactivity}

Immunoreactive levels of $\mathrm{G}_{\alpha \mathrm{i} 1 / 2}, \mathrm{G}_{\alpha \mathrm{i} 3}, \mathrm{G}_{\alpha \mathrm{o}}$ and $\mathrm{G}_{\alpha \mathrm{s}}$ were assessed by using specific polyclonal antibodies (Milligan 1988, Escribá et al. 1994). Detection by a monoclonal antibody of the cytoskeletal protein $\alpha$-tubuline was used as a loading control in each experiment. Membrane preparation aliquots were thawed and resuspended in $500 \mu \mathrm{l}$ ice-cold Tris-buffer and diluted up to $1 \mathrm{mg}$ protein $/ \mathrm{ml}$ (Bradford 1976). Samples were prepared for electrophoresis as described (Escribá et al. 1994) and subjected to SDS-polyacrylamide gel electrophoresis on $10 \%$ polyacrylamide gels. Proteins were immediately transferred to nitrocellulose membranes and incubated overnight at $4^{\circ} \mathrm{C}$ in blocking solution containing the primary antibody at 1:7,000 (anti- $\left.G_{\alpha i 1 / 2}\right), 1: 3,000$ (anti- $\left.G_{\alpha i 3}\right)$, 1:4,000 (anti- $G_{\alpha o}$ ) and 1:3,000 (anti- $G_{\alpha s}$ ) dilutions. The secondary antibody was a horseradish peroxidase-linked donkey anti-rabbit IgG at 1:5,000 dilution. Immunoreactivity was detected with an enhanced chemiluminescence (ECL) detection system (Amersham, Buckinghamshire, UK), followed by exposure to AGFA film (RP2 B3324F1) for 1-10 min. Films were scanned in an image analyzer using the NIH-IMAGE software (Bethesda, MD). The nitrocellulose membranes were stripped and $\alpha$-tubuline was detected using anti- $\alpha$-tubuline primary antibody $(1: 3,000)$ and sheep anti-mouse IgG antiserum $(1: 5,000)$ as secondary antibody.

For the quantification of the target proteins, duplicate problem samples were evaluated using standard curves (i.e., total protein loaded vs integrated optical density, IOD) which consisted of at least four points of different protein content (usually 0.25 to $4 \mu \mathrm{g}$ of membrane protein, resulting in linear relationships) loaded on the same gel. The standard curves were performed by using a membrane preparation pool of five control subjects not included in the study and who presented a wide range of age, postmortem delay and freezing storage period. Given a known amount of membrane protein (PR, real protein amount) from a problem sample loaded in a gel well, the relative amount of G-protein or $\alpha$-tubuline was calculated as the ratio between the amount of protein corresponding to the IOD value of the problem sample interpolated in the control standard curve (PT, the theoretical protein amount) and PR. The relative amount of G-protein was corrected for the relative amount of $\alpha$-tubuline of the stripped membrane, and given as percentage of immunoreactivity. This quantification procedure was repeated at least twice in different gels, for a total number of four measurements for each subject sample. The mean intra-assay and inter-assay coefficients of variation were $\sim 1 \%$ and $\sim 10 \%$, respectively.

\section{Data Analysis}

Data are presented as mean \pm S.E.M. values. Concentration-response curves for the agonist-induced stimulation of the $\left.{ }^{35} \mathrm{~S}\right] \mathrm{GTP} \gamma \mathrm{S}$ binding were performed and the pharmacological parameters were calculated by nonlinear regression analysis using the Prism ${ }^{\mathrm{TM}}$ software, (GraphPad Inc., San Diego, CA). The theoretical maximal effects fitted by the curves and the concentration of the agonist that determines the half-maximal effect $\left(\mathrm{EC}_{50}\right)$ were obtained. $\mathrm{EC}_{50}$ values were normalized as $\log \mathrm{EC}_{50}$ to be analyzed. Agonist-stimulated $\left[{ }^{35} \mathrm{~S}\right] \mathrm{GTP} \gamma \mathrm{S}$ binding is also presented as percentage of the maximal stimulation over basal, ((maximal effect minus basal) $\times 100 /$ basal), and as the maximal net stimulation (maximal effect minus basal). Student's 2-tailed $t$-test was used for statistical evaluations. The selection between binding models was made by the extra sum of squares principle (F-test). Linear regressions were calculated by the method of least squares and Pearson's coefficient for simple correlation was calculated to test for possible association among variables. The possible association between G-protein densities and [ $\left.{ }^{35} \mathrm{~S}\right] \mathrm{GTP} \gamma \mathrm{S}$ binding parameters was evaluated by a partial correlation analysis considering $\left[{ }^{35} \mathrm{~S}\right] \mathrm{GT}-$ PyS binding parameters as dependent variable and both G-protein densities and age, postmortem delay or storage period as independent variables. The level of significance was chosen as $p=.05$.

\section{Materials}

$\left.{ }^{35} \mathrm{~S}\right]$ guanosine $5^{\prime}$-( $\gamma$-thio)triphosphate (GTP $\left.\gamma \mathrm{S}\right) \quad(1250$ $\mathrm{Ci} / \mathrm{mmol}$ ) was purchased from DuPont NEN (Brussels, Belgium). Aprotinine was purchased from Bio-Rad Laboratories. Bovine seroalbumine (BSA), carbachol, [D-Ala ${ }^{2}$, $\mathrm{N}-\mathrm{Me}^{-P h e}{ }^{4}, \mathrm{Gly}^{5}$-ol]-enkephalin (DAMGO), ( \pm )-8-hydroxy2-(di-n-propylamino)tetralin (8-OH-DPAT), DL-dithiothreitol (DTT), GDP, GTP $\gamma \mathrm{S}$, N-ethylmaleimide (NEM), $\beta$-mercaptoethanol, sodium dodecylsulphate (SDS), timerosal and Tween-20 were purchased from Sigma (St. Louis, Mo, USA). Baclofen and 5-bromo-N-(4,5-dihydro1H-imidazol-2-yl)-6-quinoxalinamine (UK14304) were obtained from Tocris Cookson Inc. (Bristol, UK). Anti$\mathrm{G}_{\alpha}$-protein polyclonal antibodies raised against specific C-terminal peptides were purchased from Dupont NEN. 
Anti- $\alpha$-tubuline monoclonal antibody (clone DM 1A) was from Sigma. Secondary antibodies and ECL reagents were from Amersham. All other chemicals were obtained from standard sources and were of the highest purity commercially available.

\section{RESULTS}

\section{Modulation of Receptor-mediated Stimulation of $\left[{ }^{35} S\right] G T P \gamma S$ Binding to G-proteins and $\mathrm{G}_{\alpha}$-protein Immunoreactive Levels in Brain during Aging}

Basal levels of $\left[{ }^{35} \mathrm{~S}\right] \mathrm{GTP} \gamma \mathrm{S}$ binding to postmortem human brain membranes were negatively correlated with age (Figure 1, Panel A, Table 1). With this linear decay model, the percentage of decrease of basal $\left[{ }^{35} \mathrm{~S}\right] \mathrm{GTP} \gamma \mathrm{S}$ binding per decade was $4 \%$ relative to the estimated binding at the birth time.

The $\alpha_{2}$-adrenoceptor, $5-\mathrm{HT}_{1 \mathrm{~A}}$-serotonin, and $\mathrm{GABA}_{\mathrm{B}}$ receptor agonist-mediated stimulations showed positive correlations between their normalized $\mathrm{EC}_{50}$ values and age (i.e., the concentration-response curves were shifted to the right with increasing age) (Figure 1, Panels B and C, Figure 2, Panel A, Table 1). In marked contrast, net stimulations did not correlate significantly with age (Figure 1, Panel D for UK14304, Table 1). The concentration-response curves of $\left[{ }^{35} \mathrm{~S}\right] \mathrm{GTP} \gamma \mathrm{S}$ binding stimulation by $8-\mathrm{OH}-\mathrm{DPAT}$ fitted to a biphasic model $\left(\mathrm{F}_{2,569}=7.05 ; p<.001\right)$ show-
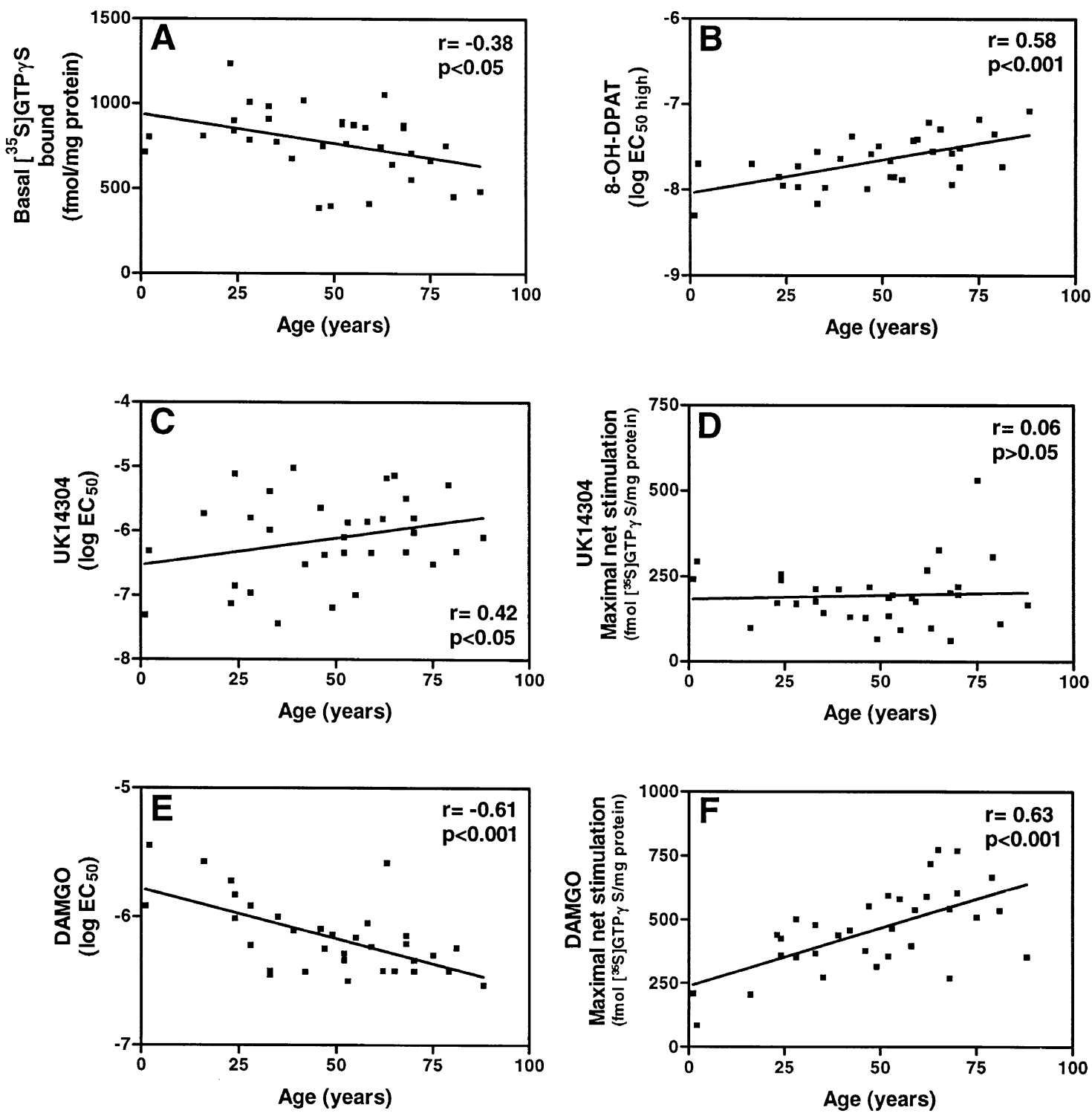

Figure 1. Age-related changes in (A) basal and (B-F) agonist-stimulated $\left.{ }^{35} \mathrm{~S}\right] \mathrm{GTP} \gamma \mathrm{S}$ binding to postmortem human brain cortical membranes. Concentration-response curves to selective agonist drugs were performed to obtain maximal stimulation and $\mathrm{EC}_{50}$ values. Maximal net stimulation (stimulated minus basal) and normalized $\mathrm{EC}_{50}\left(\log \mathrm{EC}_{50}\right)$ were calculated and expressed in linear relation to the age at death of the subjects. Estimated regression lines are represented. 
Table 1. Influence of Age, Postmortem Delay (PMD) and Freezing Storage Period on Agonist-Mediated Stimulation of $\left[{ }^{35} \mathrm{~S}\right] \mathrm{GTP} \gamma \mathrm{S}$ Binding to Postmortem Human Brain Membranes

\begin{tabular}{|c|c|c|c|c|c|c|c|c|c|c|c|c|c|}
\hline & \multirow[b]{2}{*}{ Basal } & \multicolumn{2}{|c|}{$\begin{array}{c}\text { UK14304 } \\
\left(\alpha_{2 \mathrm{~A}} \text {-adrenoceptor) }\right.\end{array}$} & \multicolumn{2}{|c|}{$\begin{array}{c}\text { DAMGO } \\
\text { ( } \mu \text {-opioid receptor) }\end{array}$} & \multicolumn{4}{|c|}{$\begin{array}{c}\text { 8-OH-DPAT } \\
\left(5-\mathrm{HT}_{1 \mathrm{~A}} \text { receptor) }\right.\end{array}$} & \multicolumn{2}{|c|}{$\begin{array}{c}\text { Baclofen } \\
\text { (GABA }{ }_{\mathrm{B}} \text { receptor) }\end{array}$} & \multicolumn{2}{|c|}{$\begin{array}{c}\text { Carbachol } \\
\text { (muscarinic receptor) }\end{array}$} \\
\hline & & NStim & $\log \mathrm{EC}_{50}$ & NStim & $\log \mathrm{EC}_{50}$ & NStim & $\log \mathrm{EC}_{50 \mathrm{H}}$ & $\log \mathrm{EC}_{50 \mathrm{~L}}$ & $\% \mathrm{H}$ & NStim & $\log \mathrm{EC}_{50}$ & NStim & $\log \mathrm{EC}_{50}$ \\
\hline & & .06 & 4 & & . & .1 & 0.5 &.- & .18 & .0 & & $-.51^{*}$ & -.05 \\
\hline PMD & -.03 & .32 & .06 & .005 & -.21 & .23 & .17 & .001 & .19 & .19 & -.07 & .21 & -.14 \\
\hline Storage & -.30 & .29 & .22 & .24 & -.15 & .29 & .24 & -.02 & .33 & .04 & .22 & .03 & .09 \\
\hline
\end{tabular}

Values represent Pearson's correlation coefficients between $\left.{ }^{35} \mathrm{~S}\right] \mathrm{GTP} \gamma \mathrm{S}$ binding pharmacological parameters and age, postmortem delay (hours) or storage period at $-70^{\circ} \mathrm{C}$ (months). Concentration-response curves to selective agonists were performed by triplicate in 34 (20 female, 14 male) human brain samples as shown in subjects and methods. The influence of age (range 1-88 years), PMD (range 8-92 h) and storage period (range 1-85 months) on basal $\left.{ }^{35} \mathrm{~S}\right] \mathrm{GTP} \gamma \mathrm{S}$ binding, normalized $\mathrm{EC}_{50}\left(\log \mathrm{EC}_{50}\right)$ and net stimulations (NStim) achieved by the agonists were studied by linear correlation analysis. 8-OH-DPAT showed a biphasic curve stimulating $\left[{ }^{35} \mathrm{~S}\right] \mathrm{GTP} \gamma \mathrm{S}$ binding (see Results) and correlation coefficients for high-affinity $\mathrm{EC}_{50}$ $\left(\mathrm{EC}_{50 \mathrm{H}}\right)$, low-affinity $\mathrm{EC}_{50}\left(\mathrm{EC}_{50 \mathrm{~L}}\right)$ and high-affinity site fraction $(\% \mathrm{H})$ were obtained.

${ }^{*} p<.05$.

$* * p<.01$

$* * * p<.001$.

ing a high-affinity $\mathrm{EC}_{50}\left(30.3 \pm 1.3 \mathrm{nM} ; \mathrm{EC}_{50 \text { high }}\right)$ and a low-affinity $\mathrm{EC}_{50}\left(59.7 \pm 6.6 \mu \mathrm{M} ; \mathrm{EC}_{50 \text { low }}\right)$. Representative individual curves are displayed in Figure 2, Panel A. Only the $\mathrm{EC}_{50}$ high values showed a significant linear correlation with age (Table 1).
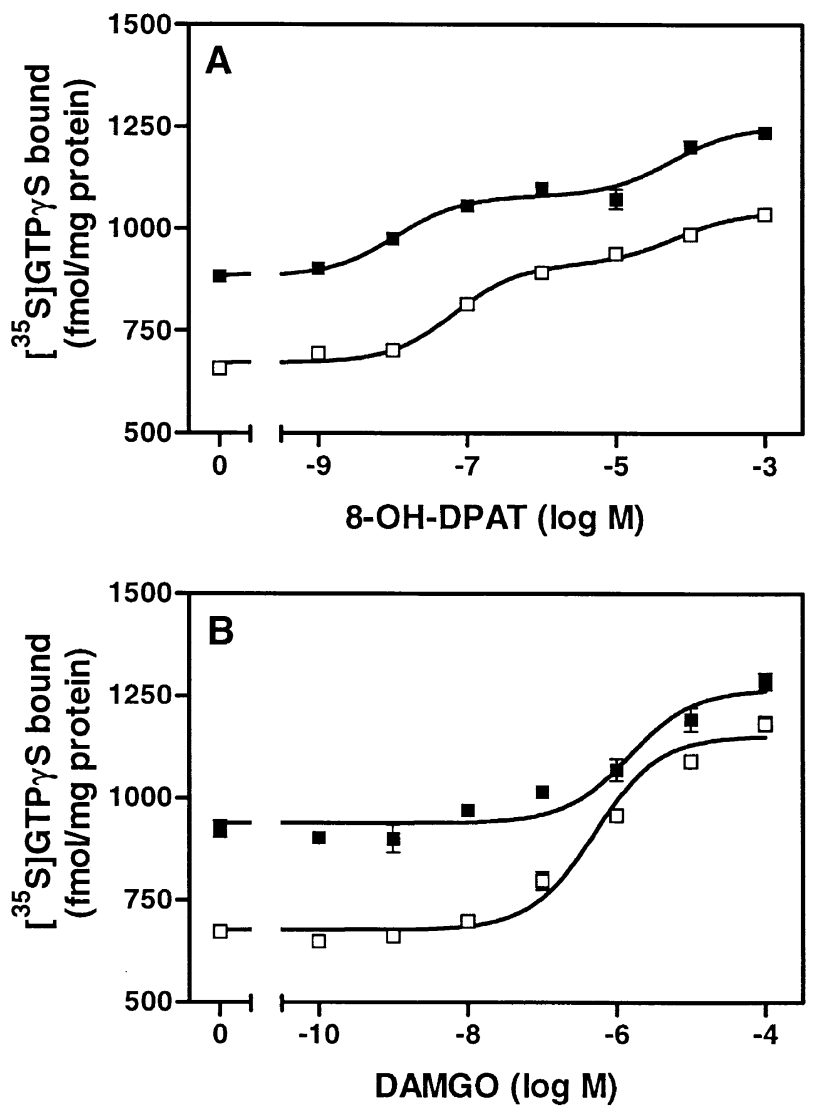

Figure 2. Representative concentration-response curves of the stimulation of $\left[{ }^{35} \mathrm{~S}\right] \mathrm{GTP} \gamma \mathrm{S}$ binding to postmortem human brain cortical membranes by 8-OH-DPAT (A) and DAMGO

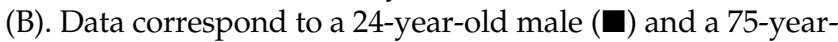
old female ( $\square$ ).
In relation to age at death, the $\left.{ }^{35} \mathrm{~S}\right] \mathrm{GTP} \gamma \mathrm{S}$ binding stimulation by the $\mu$-opioid receptor agonist DAMGO displayed a negative correlation for normalized $\mathrm{EC}_{50}$ values and a positive correlation for net stimulation values (Figure 1, Panel E and F, Table 1). Therefore, the concentration-response curves for DAMGO were shifted to the left and showed enhanced efficacy with increasing age (Figure 2, Panel B). According to this linear model, the average increase per decade for the DAMGO-induced net stimulation was $19 \%$ relative to the estimated value of net stimulation at the birth time.

Net stimulations reached by carbachol in $\left[{ }^{35} \mathrm{~S}\right] \mathrm{GTP} \gamma \mathrm{S}$ binding to postmortem human brain membranes were negatively correlated with age (Table 1). On the contrary, no significant correlation was found between normalized $\mathrm{EC}_{50}$ values for carbachol and age. The average decrease of the carbachol-induced net stimulation per decade was $6 \%$ relative to the estimated value of net stimulation at the birth time.

In the prefrontal cortex, the immunoreactive densities of $G_{\alpha i 1 / 2^{-}}$and $G_{\alpha o}$-proteins negatively correlated with age, although in the case of $G_{\alpha o}$-proteins the correlation did not reach the level of statistical significance (Figure 3, Table 2). There was no significant correlation between age at death and the levels of $\mathrm{G}_{\alpha \mathrm{i} 3^{-}}$or $\mathrm{G}_{\alpha \mathrm{s}}$ ( $(52 \mathrm{kDa}$ isoform) proteins (Table 2). With this linear model, the average decrease per decade for the $G_{\alpha i 1 / 2}$-protein density was $4 \%$ relative to the estimated value at the birth time.

\section{Relation between $\mathrm{G}_{\alpha}$-protein Immunoreactivity and $\left[{ }^{35}\right.$ S]GTP $\gamma \mathrm{S}$ Binding}

Functional receptor parameters of $\left[{ }^{35} \mathrm{~S}\right] \mathrm{GTP} \gamma \mathrm{S}$ binding were correlated with $G_{\alpha}$-protein densities. Only basal $\left[{ }^{35} \mathrm{~S}\right] \mathrm{GTP} \gamma \mathrm{S}$ binding to cortical membranes displayed a positive simple correlation with $\mathrm{G}_{\alpha \mathrm{i} 1 / 2}$-protein immunoreactive levels $(r=0.39 ; p<.05)$. As reported above, both basal $\left[{ }^{35} \mathrm{~S}\right] \mathrm{GTP} \gamma \mathrm{S}$ binding and $\mathrm{G}_{\alpha i 1 / 2}$-protein levels were 

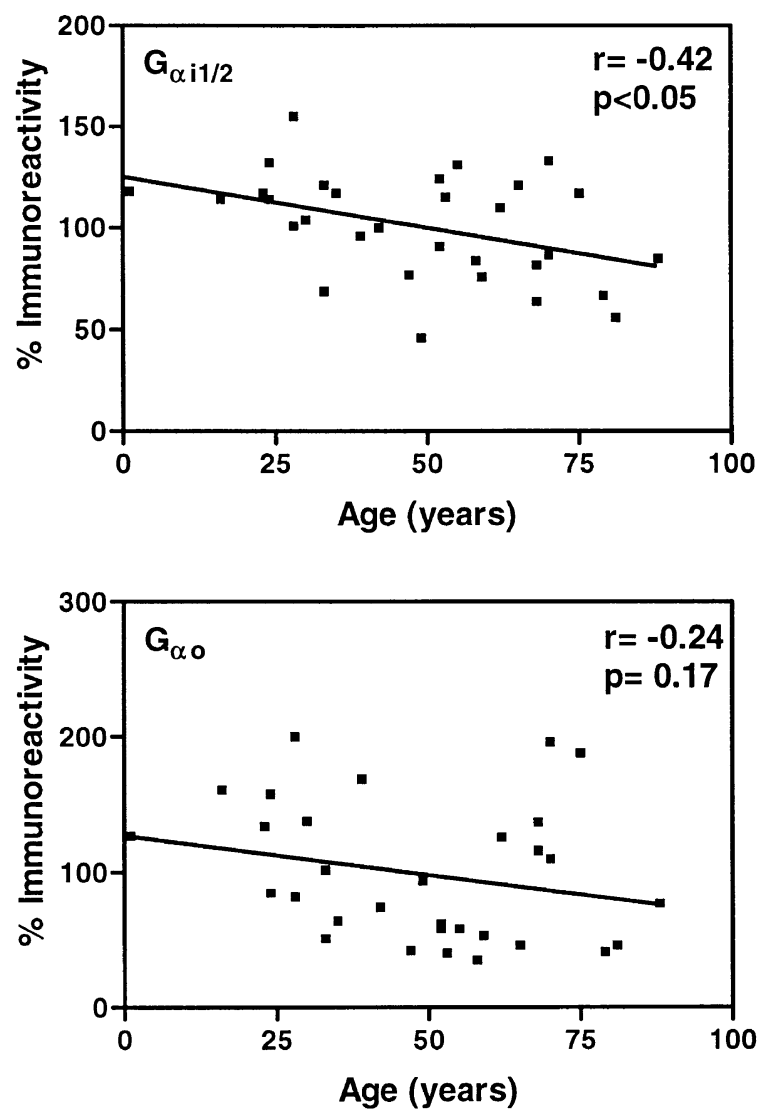

Figure 3. Age-related changes in the immunoreactive levels of $G_{\alpha i 1 / 2^{-}}$, and $G_{\alpha 0}$-proteins in cortical membranes The levels of $G_{\alpha}$-proteins were quantified by immunoblotting detection (Western blot) and extrapolation from standard curves. Estimated regression lines are represented.

negatively correlated with age (Figure 1, Panel A, and Figure 3 ). Therefore, further statistical analyses were performed in order to control for possible cross correlations between these three parameters (i.e., age, basal $\left.{ }^{35} \mathrm{~S}\right] \mathrm{GTP} \gamma \mathrm{S}$ binding, and $G_{\alpha i 1 / 2}$-protein levels). Partial correlation analysis between basal $\left[{ }^{35} \mathrm{~S}\right] \mathrm{GTP} \gamma \mathrm{S}$ binding (dependent variable), and age and $G_{\alpha i 1 / 2}$-protein levels (independent variables) showed that basal $\left[{ }^{35} \mathrm{~S}\right] \mathrm{GTP} \gamma \mathrm{S}$ binding was not correlated with $\mathrm{G}_{\alpha i 1 / 2}$-protein density $(r=0.23 ; p>.05)$ but only negatively with age $(r=-0.39 ; p<.05)$. Therefore basal $\left.{ }^{35} \mathrm{~S}\right] \mathrm{GTP} \gamma \mathrm{S}$ binding does not seem to be a direct reflect from $\mathrm{G}_{\mathrm{\alpha i1} / 2}$-protein density.

\section{Effect of Postmortem Delay on Receptor-Mediated Stimulation of $\left[{ }^{35} \mathrm{~S}\right] \mathrm{GTP} \gamma \mathrm{S}$ Binding to G-proteins and $G_{\alpha}$-protein Immunoreactive Levels in Brain}

Basal levels of $\left.{ }^{35} \mathrm{~S}\right] \mathrm{GTP} \gamma \mathrm{S}$ binding to human brain membranes did not correlate significantly with the postmortem delay (Table 1). Moreover, none of the functional receptor parameters for the $\left[{ }^{35} \mathrm{~S}\right] \mathrm{GTP} \gamma \mathrm{S}$ binding stimulations induced by the different agonists showed a correlation with
Table 2. Influence of Age, Postmortem Delay (PMD) and Freezing Storage Period on $\mathrm{G} \alpha$-protein Immunoreactive Levels in Postmortem Human Brain Membranes.

\begin{tabular}{lclrr}
\hline & $\mathrm{G}_{\alpha \mathbf{i} 1 / 2}$ & $\mathbf{G}_{\alpha \mathrm{i} 3}$ & $\mathbf{G}_{\alpha \mathbf{0}}$ & $\mathbf{G}_{\alpha \mathbf{s}}$ \\
\hline Age & $-.41^{*}$ & -.0002 & -.24 & .18 \\
PMD & -.28 & -.2 & -.11 & -.23 \\
Storage & .13 & -.08 & .13 & .25 \\
\hline
\end{tabular}

Values represent Pearson's correlation coefficients between $\mathrm{G}_{\alpha}$-protein immunoreactive levels and age, postmortem delay (hours) or storage period at $-70^{\circ} \mathrm{C}$ (months). The density of $\mathrm{G}_{\alpha \mathrm{ii} / 2^{-}}, \mathrm{G}_{\alpha \mathrm{i} 3^{-}}, \mathrm{G}_{\alpha 0^{-}}$, and $\mathrm{G}_{\mathrm{\alpha s}}(52$ $\mathrm{kDa}$ )-proteins were measured in duplicate by immunoblot analysis in 34 postmortem human brain samples (20 female, 14 male) as shown in subjects and methods. The influence of age (range 1-88 years), PMD (range 8-92 h) and freezing storage period (range 1-85 months) on $\mathrm{G}_{\alpha}$-protein immunoreactivities were studied by correlation analysis. ${ }^{*} p<.05$.

the postmortem delay within the range (8-92 h) of values analyzed in the present study (Table 1 ).

No significant linear correlation was observed between immunoreactive levels of any of the $G_{\alpha}$-proteins and the postmortem delay, although the regressions displayed negative slopes for all the G-protein $\alpha$ subunits evaluated (Table 2).

Effect of Freezing Storage Period on Receptor-Mediated Stimulation of $\left[{ }^{35} \mathrm{~S}\right] \mathrm{GTP} \gamma \mathrm{S}$ Binding to G-proteins and $\mathrm{G}_{\alpha}$-protein Immunoreactive Levels in Brain

In the absence of agonist, basal $\left[{ }^{35} \mathrm{~S}\right] \mathrm{GTP} \gamma \mathrm{S}$ binding to cortical brain membranes showed a weak negative correlation $(r=-0.30 ; p=.08)$ with the freezing storage period of the samples (1-85 months) at $-70^{\circ} \mathrm{C}$ (Figure 4, Panel A, Table 1). With this linear model, the average decrease of basal $\left[{ }^{35} \mathrm{~S}\right] \mathrm{GTP} \gamma \mathrm{S}$ binding per year of storage at $-70^{\circ} \mathrm{C}$ for the human brain samples was $3 \%$ relative to the estimated binding at the moment of storage. However, the normalized $\mathrm{EC}_{50}$ values and the net stimulation values elicited by the different agonists did not show a significant correlation with the storage time (Figure 4, Panel B for baclofen, Table 1). Therefore, the rate of stimulation (unmodified parameter) over basal levels (tendency to be decreased) presented significant correlations with freezing storage period for all the studied agonists (see Figure 4, Panel C, for baclofen).

The time of tissue storage (1-85 months) at $-70^{\circ} \mathrm{C}$ did not affect significantly the immunoreactivity of any of the analyzed $\mathrm{G}_{\alpha}$-proteins (Table 2 ).

\section{DISCUSSION}

The decline in cognitive and motor capabilities that often accompanies aging might represent the functional consequence of a decrease in the activities of signal transduction processes at neuronal level. Furthermore, age-related ef- 

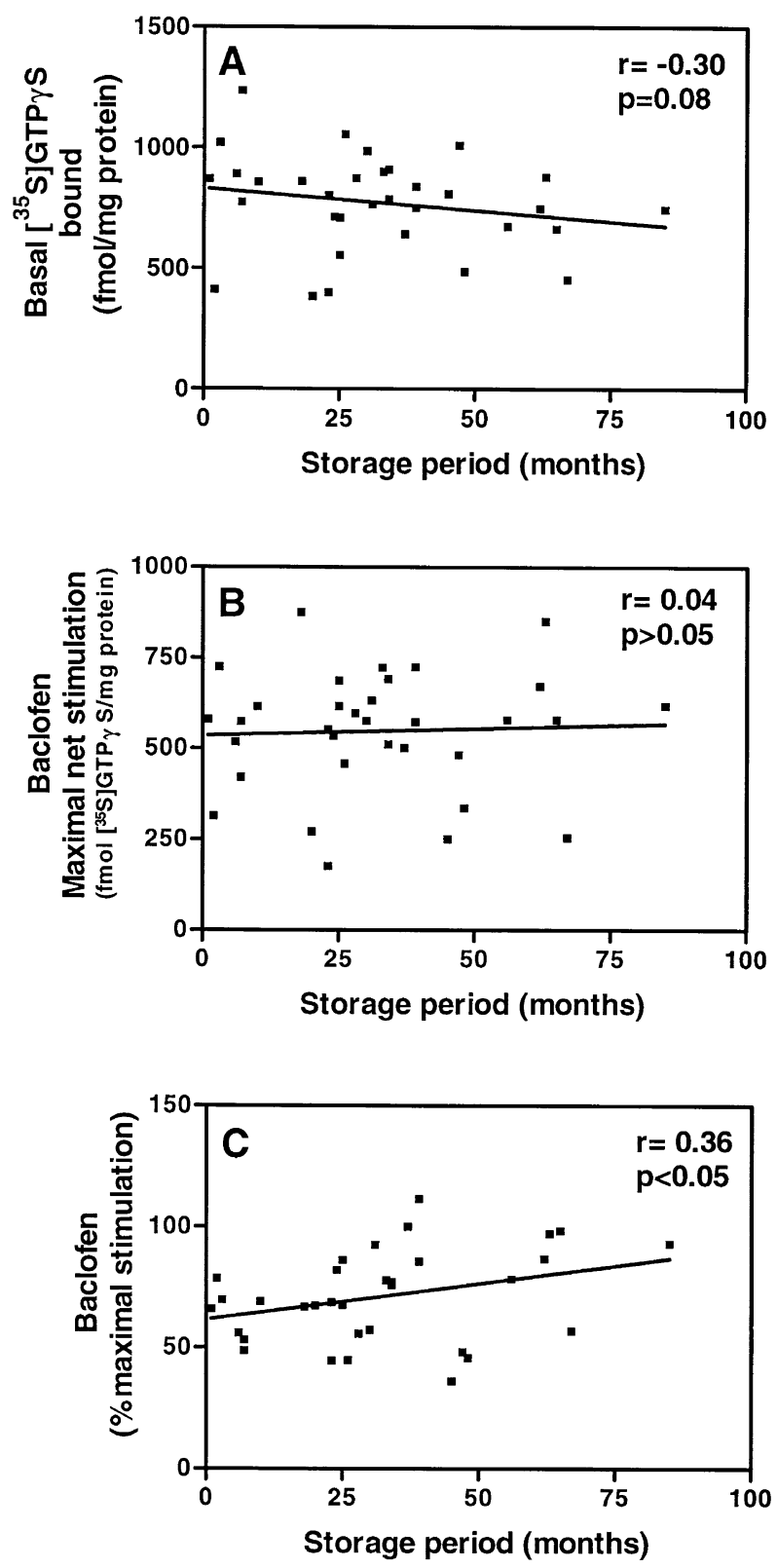

Figure 4. Storage-related changes in (A) basal $\left.{ }^{35} \mathrm{~S}\right] \mathrm{GTP} \gamma \mathrm{S}$ binding to postmortem human brain cortical membranes, (B) maximal net stimulation of $\left[{ }^{35} \mathrm{~S}\right] \mathrm{GTP} \gamma \mathrm{S}$ binding induced by the $\mathrm{GABA}_{\mathrm{B}}$ receptor agonist baclofen, and (C) maximal stimulation induced by baclofen expressed as percentage over basal values. Concentration-response curves to selective agonist drugs were performed to obtain maximal stimulation and $\mathrm{EC}_{50}$ values. Maximal net stimulation (maximal stimulation minus basal) and percentage of maximal stimulation over basal ((maximal stimulation - basal) $\times 100 /$ basal) were calculated and expressed in linear relation to the period of storage of the samples at $-70^{\circ} \mathrm{C}$. Estimated regression lines are represented. fects on G-protein density and/or activity have been suggested to be an important factor that interplay with other pathophysiological conditions in the manifestations of neuropsychiatric disorders whose incidence increase with advancing age (Scherman et al. 1989; Meana et al. 1992; Calne 1994; Cutler et al. 1994; Fülöp and Seres 1994; Greenwood et al. 1995; Li et al. 1996; Cowburn et al. 1996; Spiegel 1996). In this context, the present study has evaluated by means of both functional $\left.{ }^{35} \mathrm{~S}\right] \mathrm{GTP} \gamma \mathrm{S}$ binding and Western blot techniques the influence of aging on the G-protein signal transduction system. The influence of important variables in postmortem human brain studies such as the postmortem delay and the freezing storage period were also analyzed.

Basal G-protein activity (i.e., $\left.{ }^{35} \mathrm{~S}\right] \mathrm{GTP} \gamma \mathrm{S}$ binding in the absence of agonist) was found to progressively decrease with the age of the subject at death. This observation extends previous findings indicating that the basal activity of G-protein/adenylyl cyclase signal transduction pathway declines with aging (Cowburn et al. 1992; Ozawa et al. 1999). A similar inverse relationship was found between the immunoreactivity of $\mathrm{G}_{\alpha \mathrm{i} 1 / 2}$-proteins and age, while the immunoreactivities of other G-protein $\alpha$ subunits were not significantly changed with age. The finding should not be simply interpreted as basal $\left[{ }^{35} \mathrm{~S}\right] \mathrm{GTP} \gamma \mathrm{S}$ binding representing functional activity of $\mathrm{G}_{\mathrm{\alpha i} 1 / 2}$-proteins. In fact, when functional binding and immunoreactive values for $G_{\alpha}$-proteins were controlled for the confounding effect of age, the significant relationship between basal $\left[{ }^{35} \mathrm{~S}\right] \mathrm{GTP} \gamma \mathrm{S}$ binding and $\mathrm{G}_{\alpha \mathrm{i} 1 / 2^{-}}$ protein levels was not observed. Therefore, it is likely that basal $\left.{ }^{35} \mathrm{~S}\right] \mathrm{GTP} \gamma \mathrm{S}$ binding in postmortem human frontal cortex involves basal activity of multiple $G_{\alpha}$-proteins, and particularly of the pertussis toxin-sensitive $\mathrm{G}_{\mathrm{\alpha i} / \mathrm{o}}$-proteins (González-Maeso et al. 2000). Declines of $\mathrm{G}_{\alpha \mathrm{i}}$-protein (Young et al. 1991; Cowburn et al. 1994), and $\mathrm{G}_{\alpha \mathrm{\alpha} 1 / 2}$-protein (Sastre and García-Sevilla 1994; Ozawa et al. 1999; Sastre et al. 2001) immunoreactivity have been previously shown in human brain. The immunoreactive levels of $\mathrm{G}_{\alpha \mathrm{i} 3}$-proteins have also been found to decrease with aging (range 1 month-89 years, $\mathrm{n}=21$ ) (Sastre et al. 2001). On the contrary, Li et al., (1996) have reported no age-related changes on $\mathrm{G}_{\mathrm{\alpha i1} / 2^{-}}$ proteins in prefrontal cortex (range 19-100 years, $\mathrm{n}=$ 13). The levels of $G_{\alpha o}$-proteins presented a non-significant trend to negatively correlate with age in a similar way to previous findings in the same brain area ( $\mathrm{Li}$ et al. 1996; Ozawa et al. 1999; Sastre et al. 2001). In contrast, in parietal cortex, no age-related changes of $\mathrm{G}_{\alpha 0^{-}}$ proteins levels have been shown (range 3 days to 92 years, $n=18$ ) (Young et al. 1991). $G_{\alpha s}$-proteins (52 kDa isoform) immunoreactive levels presented a slight but not significant increase with aging. Similar results have been reported for $\mathrm{G}_{\alpha \mathrm{s}}$-proteins in prefrontal cortex (Li et al. 1996) with significant positive correlation in one study (Cowburn et al. 1994). On the other hand, an in- 
verse relationship between $G_{\alpha s}$-protein densities and age has also been reported in frontal (Ozawa et al. 1999; Sastre et al. 2001), and parietal (Young et al. 1991) brain cortex. The discrepancies between studies might be a consequence of the brain area analyzed, the type of antibody used for the immunodetection, the number of subjects included in the analysis or the distribution and range of their age at death. In the present work, a larger number of individuals $(n=34)$ presenting well spread ages (1-88 years) were included in order to improve the discrimination power of the statistical analysis.

The human brain contains the three subtypes of $\alpha_{2}$ adrenoceptors $\left(\alpha_{2 \mathrm{~A}}, \alpha_{2 \mathrm{~B}}, \alpha_{2 \mathrm{C}}\right)$ although the predominant one, especially in the prefrontal cortex, is the $\alpha_{2 A^{-}}$ adrenoceptor subtype (Grijalba et al. 1996). The present results show a decrease in the potency of the $\alpha_{2}$-adrenoceptor agonist UK14304 to stimulate G-proteins with increasing age (i.e., increase of the $\mathrm{EC}_{50}$ values), whereas $\left[{ }^{35} \mathrm{~S}\right]$ GTP $\gamma \mathrm{S}$ binding net stimulation reached by the agonist did not show any correlation. Age-related decreases in the density of $\alpha_{2}$-adrenoceptors without changes in affinity have been reported by using radiolabeled agonists (Pascual et al. 1991; Meana et al. 1992) and antagonists (Sastre and García-Sevilla 1994). These results taken together with those herein described imply that a reduction in the high-affinity conformation of the receptor originates a decrease in the potency, but not in the efficacy, of the $\alpha_{2 \mathrm{~A}}$-adrenoceptor agonist UK14304 to promote signal transduction mechanisms. Because of the predominant presynaptic location of $\alpha_{2 \mathrm{~A}}$-adrenoceptors, the age-related decreases of the UK14304 potency to stimulate $\left[{ }^{35} \mathrm{~S}\right] \mathrm{GTP} \gamma \mathrm{S}$ binding and the previously reported declines of receptor density (Pascual et al. 1991; Meana et al. 1992) could be related to the loss of noradrenergic nerve terminals arising from the locus coeruleus, which are known to degenerate with aging (Vijayashankar and Brody 1979; Mann et al. 1983).

An increase in the efficacy of the $\mu$-opioid receptor agonist DAMGO to activate G-proteins ([ $\left.{ }^{35} \mathrm{~S}\right] \mathrm{GTP} \gamma \mathrm{S}$ net stimulation) is presented with aging; furthermore, the potency of DAMGO to promote guanine nucleotide exchange on $\mathrm{G}_{\alpha}$-protein subunits is increased with advancing age. Previous studies have also demonstrated an age-related increase of $\mu$-opioid receptor density in human brain by using [ $\left.{ }^{3} \mathrm{H}\right] \mathrm{DAMGO}$ binding (Gabilondo et al. 1995), and of $\mu$-opioid receptor binding potential $\left(\mathrm{B}_{\max } / \mathrm{K}_{\mathrm{D}}\right)$ by in vivo positron emission tomography (PET) (Zubieta et al. 1999). Therefore, the possibility arises that enhanced $\mu$-opioid receptormediated activity of G-protein is related to an overexpression of $\mu$-opioid receptors with increased functional coupling to G-proteins.

The concentration-response curves to the $5-\mathrm{HT}_{1 \mathrm{~A}^{-}}$ serotonin receptor agonist 8-OH-DPAT showed a biphasic pattern stimulating $\left.{ }^{35} \mathrm{~S}\right] \mathrm{GTP} \gamma \mathrm{S}$ binding in human prefrontal cortex and only the potency of the high-affin- ity component displayed a decrease with aging. Further work is needed to clarify the identity of the low-affinity component of 8-OH-DPAT-mediated simulation of $\left[{ }^{35} \mathrm{~S}\right] \mathrm{GTP} \gamma \mathrm{S}$ binding in human prefrontal cortex. These results are concordant with those reported previously showing a decrease of $5-\mathrm{HT}_{1 \mathrm{~A}}$-serotonin receptor density in the human brain cortex (Dillon et al. 1991; Burnet et al. 1994). However, [ ${ }^{35}$ S]GTP $\gamma S$ binding net stimulation induced by 8-OH-DPAT did not correlate with age, which suggest that the decline of the agonist activity is related more to the disappearance of receptors expressed by neurons degenerating progressively with aging than to a loss of their functional coupling to G-proteins.

Similar behavior to that presented by UK14304 and 8-OH-DPAT (i.e., decreased potency as age increases without changes in $\left[{ }^{35} \mathrm{~S}\right] \mathrm{GTP} \gamma \mathrm{S}$ binding net stimulation) was shown by the $\mathrm{GABA}_{\mathrm{B}}$ receptor agonist baclofen. Although no previous information is available about human $\mathrm{GABA}_{\mathrm{B}}$ receptor evolution with aging, a decrease between postnatal day 28 and adulthood has been described in rat brain (Turgeon and Albin 1994; Happe et al. 1999). In contrast to the above mentioned receptors, the acetylcholine muscarinic agonist carbachol displayed a negative correlation between net stimulation of $\left[{ }^{35} \mathrm{~S}\right] \mathrm{GTP} \gamma \mathrm{S}$ binding and age at death without changes in $\mathrm{EC}_{50}$ values. The finding likely represents the activation of G-proteins by different muscarinic M receptors which could be differently regulated and expressed during aging. Non-selective decreases of the in vitro muscarinic receptor density (Rinne 1987; Giacobini et al. 1989; Giacobini 1990; Nordberg et al. 1992) and in vivo (PET) binding potential (Dewey et al. 1990; Lee et al. 1996) have been reported with increasing age in human brain cortex. Since muscarinic $M$ receptors are coupled to pertussis toxin-sensitive $\left(\mathrm{G}_{\alpha \mathrm{i} / \mathrm{o}}\right)$ and pertussis toxin-insensitive $\left(G_{\alpha q / 11}\right)$ G-proteins, further studies with selective agonists are needed to assess the biochemical and functional regulation of the different $M$ receptor subtypes during the process of aging.

Neuropsychiatric disorder studies in postmortem human brain tissue are performed usually by matching cases and controls by sex and age of the subjects. Inherent variables such as the postmortem delay or the freezing storage period may produce changes that could alter the result of the analysis (Perry and Perry 1983; Whitehouse et al. 1984; Burke and Greenbaum 1987; Rodríguez-Puertas et al. 1996; Paul et al. 1997). In this context, the present data show that the postmortem delay did not affect either the receptor-mediated activity or the immunoreactive levels of G-proteins within the range analyzed (8-92 h). It seems that within these time limitations, no important effects of postmortem delay on receptor densities and activities are induced when the corpse is stored early at refrigeration temperature $\left(\sim 4^{\circ} \mathrm{C}\right)$ (Whitehouse et al. 1984; Rodríguez-Puertas et al. 
1996; Paul et al. 1997; Palego et al. 1999). Immunoreactive levels of $G_{\alpha}$-proteins have been shown not to be affected by the postmortem delay at $4^{\circ} \mathrm{C}$ (Young et al. 1991; Escribá et al. 1994; Sastre and García-Sevilla 1994; Dowlatshahi et al. 1999) but some groups have reported decreases of $G_{\alpha 0^{-}}$(Li et al. 1996), and increases of $G_{\alpha i}{ }^{-}$ protein (Cowburn et al. 1994) immunoreactivities.

The effect of storage time of the human brain samples at $-70^{\circ} \mathrm{C}$ was analyzed and only basal $\left[{ }^{35} \mathrm{~S}\right] \mathrm{GTP} \gamma \mathrm{S}$ binding showed a weak negative correlation with storage period without being affected $\mathrm{EC}_{50}$ or net stimulation values achieved by the different agonist drugs. The immunoreactivity of $\mathrm{G}_{\alpha}$-proteins was not altered by storage periods. In general, it is assumed that most biochemical activities are stable for several years when tissue is stored at very low temperature $\left(-70^{\circ} \mathrm{C}\right.$ or less) (Perry and Perry 1983) whereas decreases of the receptor density have been clearly demonstrated when postmortem human brain samples are stored at $-25^{\circ} \mathrm{C}$ (Rodríguez-Puertas et al. 1996).

To our knowledge, this is the first study evaluating the influence of age, postmortem delay and freezing storage time on functional $\left[{ }^{35} \mathrm{~S}\right] \mathrm{GTP} \gamma \mathrm{S}$ binding to postmortem human brain. The present findings further demonstrate the influence of aging on the G-protein signal transduction system. The data also confirm the importance of examining potential artifacts that may alter receptor-G-protein coupling and, thus, impair a clear interpretation of the specific role of transduction mechanisms in different neuropsychiatric diseases.

\section{ACKNOWLEDGMENTS}

This study was supported by grants from FIS (01/0358), the Basque Government (PI98/8) and the University of the Basque Country (G13/98), Spain to JJM, and from FNSRS (32.57066.99), Switzerland to JAG-S. JG-M was recipient of a predoctoral fellowship from MEC, Spain. The authors wish to thank the staff members of the Basque Institute of Legal Medicine, Bilbao, and the Department of Forensic Medicine, Geneva, for their cooperation in the study. JAG-S is a member of the Institut d'Estudis Catalans (Barcelona, Spain).

\section{REFERENCES}

Arranz B, Eriksson A, Mellerup E, Plenge P, Marcusson J (1993): Effect of aging in human cortical pre- and postsynaptic serotonin binding sites. Brain Res 620:163-166

Birnbaumer L, Abramowitz J, Brown AM (1990): Receptoreffector coupling by $\mathrm{G}$ proteins. Biochim Biophys Acta 1031:163-224

Bradford MM (1976): A rapid and sensitive method for the quantitation of microgram quantities of protein utilizing the principle of protein-dye binding. Anal Biochem 72:248-254

Burke RE, Greenbaum D (1987): Effect of postmortem fac- tors on muscarinic receptor subtypes in rat brain. J Neurochem 49:592-596

Burnet PW, Eastwood SL, Harrison PJ (1994): Detection and quantitation of $5-\mathrm{HT}_{1 \mathrm{~A}}$ and $5-\mathrm{HT}_{2 \mathrm{~A}}$ receptor mRNAs in human hippocampus using a reverse transcriptasepolymerase chain reaction (RT-PCR) technique and their correlation with binding site densities and age. Neurosci Lett 178:85-89

Busquets X, Ventayol P, Sastre M, García-Sevilla JA (1996): Age-dependent increases in protein kinase $C-\alpha \beta$ immunoreactivity and activity in the human brain: possible in vivo modulatory effects on guanine nucleotide $G_{i}$ proteins. Brain Res 710:28-34

Calne DB (1994): Is idiopathic parkinsonism the consequence of an event or a process? Neurology 44:5-10

Cerione RA, Regan JW, Nakata H, Codina J, Benovic JL, Gierschik P, Somers RL, Spiegel AM, Birnbaumer L, Lefkowitz RJ, Caron MG (1986): Fuctional reconstitution of the $\alpha_{2}$-adrenergic receptor with guanine nucleotide regulatory proteins in phospholipid vesicles. J Biol Chem 261:3901-3909

Cowburn RF, O'Neill C, Ravid R, Alafuzoff I, Winblad B, Fowler CJ (1992): Adenylyl cyclase activity in postmortem human brain: evidence of altered G-protein mediation in Alzheimer's disease. J Neurochem 58:1409-1419

Cowburn RF, Marcusson JO, Eriksson A, Wiehager B, O'Neill C (1994): Adenylyl cyclase activity and G-protein subunit levels in postmortem frontal cortex of suicide victims. Brain Res 633:297-304

Cowburn RF, Wiehager B, Ravid R, Winblad B (1996): Acetylcholine muscarinic $\mathrm{M} 2$ receptor stimulated [ $\left.{ }^{35} \mathrm{~S}\right] \mathrm{GTP} \gamma \mathrm{S}$ binding shows regional selective changes in Alzheimer's disease postmortem brain. Neurodegeneration $5: 19-26$

Cutler R, Joseph JA, Yamagami K, Villalobos-Molina R, Roth GS (1994): Area specific alterations in muscarinic stimulated low $\mathrm{K}_{\mathrm{m}}$ GTPase activity in aging and Alzheimer's disease: implications for altered signal transduction. Brain Res 644:54-60

Dewey SL, Volkow ND, Logan J, MacGregor RR, Fowler JS, Schyler DJ, Bendriem B (1990): Age-related decreases in muscarinic cholinergic receptor binding in the human brain measured with positron emission tomography (PET). J Neurosci Res 27:569-575

Dillon KA, Gross-Isseroff R, Israeli M, Biegon A (1991): Autoradiographic analysis of serotonin $5-\mathrm{HT}_{1 \mathrm{~A}}$ receptor binding in the human brain postmortem: effects of age and alcohol. Brain Res 554:56-64

Dowlatshahi D, MacQueen GM, Wang J-F, Reiach JS, Young LT (1999): G protein-coupled cyclic AMP signaling in postmortem brain of subjects with mood disorders: effects of diagnosis, suicide, and treatment at the time of death. J Neurochem 73:1121-1126

Dupuis DS, Pauwels PJ, Radu D, Hall H (1999): Autoradiographic studies of $5-\mathrm{HT}_{1 \mathrm{~A}}$-receptor-stimulated $\left[{ }^{35} \mathrm{~S}\right] \mathrm{GTP} \gamma \mathrm{S}-$ binding responses in the human and monkey brain. Eur J Neurosci 11:1809-1817

Elliot J, Reynolds GP (1999): Agonist-stimulated GTP $\gamma\left[{ }^{35} \mathrm{~S}\right]$ binding to $5-\mathrm{HT}_{1 \mathrm{~A}}$ receptors in human post-mortem brain. Eur J Pharmacol 386:313-315

Escribá PV, Sastre M, García-Sevilla JA (1994): Increased 
density of guanine nucleotide-binding proteins in the postmortem brains of heroin addicts. Arch Gen Psychiatry 51:494-501

Florio VA, Sternweis PC (1989): Mechanisms of muscarinic receptor action on $G_{0}$ in reconstituted phospholipid vesicles. J Biol Chem 264:3909-3915

Friedman E, Wang H-Y (1996): Receptor-mediated activation of $\mathrm{G}$ proteins is increased in postmortem brains of bipolar affective disordes subjects. J Neurochem 67:1145-1152

Fülöp Jr T, Seres I (1994): Age-related changes in signal transduction. Implications for neuronal transmission and potential for drug intervetion. Drugs Aging 5:366-390

Gabilondo AM, Meana JJ, García-Sevilla JA (1995): Increased density of $\mu$-opioid receptors in the postmortem brain of suicide victims. Brain Res 682:245-250

Gessi S, Campi F, Varani K, Borea PA (1999): $\alpha_{2}$-Adrenergic agonist modulation of $\left[{ }^{35} \mathrm{~S}\right] \mathrm{GTP} \gamma \mathrm{S}$ binding to guaninenucleotide-binding-proteins in human platelet membranes. Life Sci 64:1403-1413

Giacobini E, DeSarno P, Clark B, Mcllhany M (1989): The cholinergic receptor system of the human brain: neurochemical and pharmacological aspects in aging and Alzheimer. Prog Brain Res 79:335-343

Giacobini E (1990): Cholinergic receptors in human brain: effects of aging and Alzheimer disease. J Neurosci Res 27:548-560

Gilman GA (1987): G proteins: transducers of receptor-generated signals. Annu Rev Biochem 56:615-649

Greenwood AF, Powers RE, Jope RS (1995): Phosphoinositide hydrolysis, G $\alpha q$, phospholipase $C$, and protein kinase $C$ in post mortem human brain: effects of post mortem interval, subject age and Alzheimer's disease. Neuroscience 69:125-138

González-Maeso J, Rodríguez-Puertas R, Gabilondo AM, Meana JJ (2000): Characterization of receptor-mediated $\left[{ }^{35} \mathrm{~S}\right] \mathrm{GTP} \gamma \mathrm{S}$ binding to cortical membranes from postmortem human brain. Eur J Pharmacol 390:25-36

Grijalba B, Callado LF, Meana JJ, García-Sevilla JA, Pazos A (1996): $\alpha_{2}$-Adrenoceptor subtypes in the human brain: a pharmacological delineation of $\left[{ }^{3} \mathrm{H}\right] \mathrm{RX}-821002$ binding to membranes and tissue sections. Eur J Pharmacol 310:83-93

Gudermann T, Schöneberg T, Schultz G (1997): Functional and structural complexity of signal transduction via G-protein-coupled receptors. Annu Rev Neurosci 20:399-427

Happe HK, Bylund DB, Murrin LC (1999): Alpha-2 adrenergic receptor functional coupling to $G$ proteins in rat brain during postnatal development. J Pharmacol Exp Ther 288:1134-1142

Hilf G, Gierschik P, Jakobs KH (1989): Muscarinic acetylcholine receptor-stimulated binding of guanosine 5'-O(3-thiotriphosphate) to guanine-nucleotide-binding proteins in cardiac membranes. Eur J Biochem 186:725-731

Jope RS, Song L, Grimes CA, Pacheco MA, Dilley GE, Li X, Meltzer HY, Overholser JC, Stockmeier CA (1998): Selective increases in phosphoinositide signaling activity and $G$ protein levels in postmortem brain from subjects with schizophrenia or alcohol dependence. J Neurochem 70:763-771

Lazareno S, Birdsall NJM (1993): Pharmacological characterization of acetylcholine-stimulated $\left[{ }^{35} \mathrm{~S}\right]-\mathrm{GTP} \gamma \mathrm{S}$ binding mediated by human muscarinic $\mathrm{m} 1-\mathrm{m} 4$ receptors: antagonists studies. Br J Pharmacol 109:1120-1127

Lee KS, Frey KA, Koeppe RA, Buck A, Mulholland GK, Kuhl DE (1996): In vivo quantification of cerebral muscarinic receptors in normal human aging using positron emission tomography and $\left[{ }^{11} \mathrm{C}\right]$ tropanyl benzilate. J Cereb Blood Flow Metab 16:303-310

Li X, Greenwood AF, Powers R, Jope RS (1996): Effects of postmortem interval, age, and Alzheimer's disease on G-proteins in human brain. Neurobiol Aging 17:115-122

Manji HK (1992): G proteins: implications for psychiatry. Am J Psychiatry 149:746-760

Mann DMA, Yates PO, Hawks J (1983): Pathology of the human locus coeruleus. Clin Neuropathol 2:1-7

Meana JJ, Barturen F, Garro MA, García-Sevilla JA, Fontán A, Zarranz JJ (1992): Decreased density of presynaptic $\alpha_{2}$-adrenoceptors in postmortem brains of patients with Alzheimer's disease. J Neurochem 58:1896-1904

Meana JJ, González-Maeso J, García-Sevilla JA, Guimón J (2000): $\mu$-Opioid receptor and $\alpha_{2}$-adrenoceptor agonist stimulation of $\left[{ }^{35} \mathrm{~S}\right] \mathrm{GTP} \gamma \mathrm{S}$ to G-proteins in postmortem brains of opioid addicts. Mol Psychiatry 5:308-315

Milligan G (1988): Techniques used in the identification and analysis of function of pertussis toxin-sensitive guanine nucleotide binding proteins. Biochem J 255:1-13

Newman-Tancredi A, Conte C, Chaput C, Verrièle L, Millan MJ (1997): Agonist and inverse agonist efficacy at human recombinant serotonin $5-\mathrm{HT}_{1 \mathrm{~A}}$ receptors as function of receptor: G-protein stoichiometry. Neuropharmacology 36:451-459

Nordberg A, Alafuzoff I, Winblad B (1992): Nicotinic and muscarinic subtypes in the human brain: changes with aging and dementia. J Neurosci Res 31:103-111

Odagaki Y, Nishi N, Ozawa H, Saito T, Takahata N, Riederer P, Koyama T (1998): Measurement of receptormediated functional activation of $\mathrm{G}$ proteins in postmortem human brain membranes. Brain Res 789:84-91

Olianas MC, Onali P (1996): Stimulation of guanosine 5'-O(3-[ $\left.{ }^{35} \mathrm{~S}\right]$ thiotriphosphate) binding by cholinergic muscarinic receptors in membranes of rat olfactory bulb. J Neurochem 67:2549-2556

Ozawa H, Ukai W, Kornhuber J, Yamaguchi T, Froelich L, Ikeda H, Saito T, Riederer P (1999): Postnatal ontogeny of GTP binding protein in the human frontal cortex. Life Sci 65:2315-2323

Pacheco MA, Stockmeier C, Meltzer HY, Overholser JC, Dilley GE, Jope RS (1996): Alterations in phosphoinositide signalling and G-protein levels in depressed suicide brain. Brain Res 723:37-45

Palego L, Giromella A, Marazziti D, Borsini F, Naccarato AG, Giannaccini G, Lucacchini A, Cassano GB, Mazzoni MR (1999): Effects of postmortem delay on serotonin and (+)8-OH-DPAT-mediated inhibition of adenylyl cyclase activity in rat and human tissues. Brain Res 816:165-174

Pascual J, del Arco C, González AM, Díaz A, del Olmo E, Pazos A (1991): Regionally specific age-dependent decline in $\alpha_{2}$-adrenoceptors: an autoradiographic study in human brain. Neurosci Lett 133:279-283

Paul D, Gauthier CA, Minor LD, Gonzales GR (1997): The effects of postmortem delay on mu, delta and kappa 
opioid receptor subtypes in rat brain and guinea pig cerebellum evaluated by radioligand receptor binding. Life Sci 61:1993-1998

Peltonen JM, Pihlavisto M, Scheinin M (1998): Subtype-specific stimulation of $\left[{ }^{35} \mathrm{~S}\right] \mathrm{GTP} \gamma \mathrm{S}$ binding by recombinant $\alpha_{2}$-adrenoceptors. Eur J Pharmacol 355:275-279

Perry EK, Perry RH (1983): Human brain neurochemistry. Some postmortem problems. Life Sci 33:1733-1743

Rinne JO (1987): Muscarinic and dopaminergic receptors in the aging human brain. Brain Res 404:162-168

Rodríguez-Puertas R, Pascual J, Pazos A (1996): Effects of freezing storage time on the density of muscarinic receptors in the human postmortem brain: an autoradiographic study in control and Alzheimer's disease brain tissues. Brain Res 728:65-71

Rodríguez-Puertas R, González-Maeso J, Meana JJ, Pazos A (2000): Autoradiography of receptor-activated G-proteins in postmortem human brain. Neuroscience 96:169-180

Sastre M, García-Sevilla JA (1994): Density of alpha-2 adrenoceptors and $G_{i}$ proteins in the human brain: ratio of high-affinity agonist sites to antagonist sites and effect of age. J Pharmacol Exp Ther 269:1062-1072

Sastre M, Guimón J, García-Sevilla JA (2001): Relationship between $\beta$ - and $\alpha_{2}$-adrenoceptors and $G$ coupling proteins in the human brain: Effects of age and suicide. Brain Res 898:242-255

Scherman D, Desnos C, Darchen F, Pollak P, Javoy-Agid F, Agid Y (1989): Striatal dopamine deficiency in Parkinson's disease: role of aging. Ann Neurol 26:551-557

Sim LJ, Selley DE, Childers SR (1995): In vitro autoradiography of receptor-activated G-proteins in rat brain by agonist-stimulated guanylyl $5^{\prime}-\left[\gamma-\left[{ }^{35} S\right]\right.$ thio $]$-triphosphate binding. Proc Natl Acad Sci USA 92:7242-7246

Simon MI, Strathmann MP, Gautam N (1991): Diversity of G proteins in signal transduction. Science 252:802-808

Spiegel AM (1996): Defects in G protein-coupled signal transduction in human disease. Annu Rev Physiol 58:143-170

Turgeon SM, Albin RL (1994): Postnatal ontogeny of GABA binding in rat brain. Neuroscience 62:601-613

Vijayashankar N, Brody H (1979): A quantitative study of the pigmented neurons in the nuclei locus coeruleus and subcoeruleus in man as related to aging. J Comp Neurol 38:490-497

Wang H-Y, Friedman E (1994): Receptor-mediated activation of $G$ proteins is reduced in postmortem brains from Alzheimer's disease patients. Neurosci Lett 173:37-39

Whitehouse PJ, Lynch D, Kuhar MJ (1984): Effects of postmortem delay and temperature on neurotransmitter receptor binding in a rat model of the human autopsy process. J Neurochem 43:553-559

Young LT, Warsh JJ, Li PP, Siu KP, Becker L, Gilbert J, Hornykiewicz O, Kish SJ (1991): Maturational and aging effects on guanine nucleotide binding protein immunoreactivity in human brain. Dev Brain Res 61:243-248

Young LT, Li PP, Kish SJ, Siu KP, Kamble A, Hornykiewicz O, Warsh JJ (1993): Cerebral cortex $\mathrm{G}_{\mathrm{s}} \alpha$ protein levels and forskolin-stimulated cyclic AMP formation are increased in bipolar affective disorder. J Neurochem 61:890-898

Zubieta JK, Dannals RF, Frost JJ (1999): Gender and age related influences of human brain mu-opioid receptor binding measured by PET. Am J Psychiatry 156:842-848 